\title{
The impact of seed industry concentration on innovation: a study of US biotech market leaders
}

\author{
David E. Schimmelpfennig ${ }^{\mathrm{a}, *}$, Carl E. Pray ${ }^{\mathrm{b}}$, Margaret F. Brennan ${ }^{\mathrm{c}}$ \\ ${ }^{a}$ Economic Research Service, US Department of Agriculture, Resource Economics Division, \\ 1800 M Street, NW, Room 4195, Washington, DC 20036-5831, USA \\ ${ }^{\mathrm{b}}$ Department of Agricultural, food and Resource Economics, Rutgers University, USA \\ ${ }^{c}$ Cook College Office of Research, Rutgers University, USA
}

Received 18 April 2001; received in revised form 1 June 2002; accepted 6 November 2002

\begin{abstract}
Agricultural research drives increases in agricultural productivity, and the number of private agricultural input firms has been declining. The empirical relationship between the number of firms doing applied biotechnology crop research and the amount of research output they produce is investigated in a research profit function model. Increases in seed industry concentration have reduced biotech research intensity in the United States in the 1990s. Concentration and research are simultaneously determined and are influenced by the appropriability of research results and the state of technological opportunity.

(C) 2003 Elsevier B.V. All rights reserved.
\end{abstract}

JEL classification: L1; Q16; C3

Keywords: Industrial organisation; Biotechnology R\&D

\section{Introduction}

Productivity growth has an important influence on the competitiveness and profitability of international agriculture. To remain in business agricultural producers have often had to adopt new technologies. Some of these innovations have been embodied in mechanical inputs that have replaced labour. Other new inputs, like high-yielding seed varieties and chemical herbicides and pesticides, have increased land productivity. These new technologies have led to post-war total factor productivity growth in agriculture that is almost

\footnotetext{
* Corresponding author. Tel.: +1-202-694-5507; fax: +1-202-694-5774.

E-mail address: des@ers.usda.gov (D.E. Schimmelpfennig).
}

four times the growth rate in the non-farm economy in the US (Jorgenson and Gollop, 1992).

Huffman and Evenson (1992) showed that both public and private research were major contributors to productivity growth in the post-war period. The relative importance of the public and private sectors has been changing around the world, but particularly in the US. Private sector spending on agricultural research and development (R\&D) more than doubled in the US between 1970 and 1996, from 2 to 4.2 billion US dollars (bUS\$). Public Federal and State research have been stagnant at a little over 1.5 and 1 bUS\$, respectively, since 1978 (Fuglie, 2000).

In the 1990s, the private sector made major investments in agricultural biotechnology research. Just and Hueth (1993) link the direction of biotechnology in- 
novation to market structure. They argued that chemical companies would develop biological innovations that increase dependence on the chemicals that they sell. Ollinger and Pope (1995) empirically tested Just and Hueth's theoretical findings using the numbers of permits for pre-market field tests of genetically modified crops from the US Department of Agriculture's (USDA) Animal Plant Health and Inspection Service (APHIS). They did not find empirical support for the Just and Hueth hypothesis.

The large number of mergers and acquisitions in agricultural inputs industries around the world raises the question whether more concentrated markets increase or decrease the level of biotechnology research, and future increases in agricultural productivity. Other than the studies mentioned in the previous paragraph, there have been no empirical studies of the links between the structure of the agricultural input industries and the amount of R\&D. Furthermore, for all industries there are few indicators to help the Federal Trade Commission (FTC) or Department of Justice in the US, or their counterparts around the world, identify whether the level of concentration in the innovation market is in some sense sub-optimal. We develop a simultaneous theoretical model of concentration in the innovation market and private $R \& D$ intensity in an attempt to answer this question.

Of course, industry structure is not the only factor that can influence the amount of private research. Public R\&D and stronger intellectual property rights (IPRs) could also induce more private R\&D. Thus our model also includes variables for public research and IPRs. We test the model with private R\&D measured by data on biotech field trials of corn, cotton and soybeans divided by total (biotech and non-biotech) US market seed sales to control for potential market size.
The answers to these questions will be of interest to policymakers and officials in antitrust regulation who are concerned with levels of seed and biotech industry concentration. We provide some of the first estimates of the effects of concentration in these industries. The results should also be of interest to administrators in public research institutions and people in charge of IPRs. The next section reviews the recent stylised facts about US corn, cotton and soybean production and the influence of biotechnology on these crops. The following sections introduce the theoretical model and test it using aggregate US data. The last section examines some of the policy implications of our results.

\section{Corn, cotton and soybean production, industry consolidation, and the spread of genetically modified varieties}

This study focuses on corn, cotton and soybeans because genetically modified (GM) varieties of these three crops cover most of the total area of GM crops in the US. Table 1 presents some of the characteristics of the US markets for and research efforts on these crops. Total area planted to transgenic varieties remained quite large in 2000. Round-up Ready ${ }^{\mathrm{TM}}$ soybeans cover the most area followed by insect resistant (Bt) corn, Bt cotton and cotton with stacked $\mathrm{Bt}$ and Round-up Ready (RR) genes. The spread of GM varieties in these crops is partially the result of large investments in plant breeding and biotech research that have focused on these crops. Corn has attracted far more plant breeding and biotech research resources than any other crop (see last column in Table 1), and has had the largest number of transgenic varieties approved for commercial use (see next to last column of

Table 1

Characteristics of US biotech markets and research on corn, cotton and soybeans

\begin{tabular}{lllllll}
\hline & $\begin{array}{l}\text { Area planted in } \\
\text { US, 2000 } \\
\text { (millions of acres) }\end{array}$ & $\begin{array}{l}\text { Area of transgenic } \\
\text { varieties, 2000 } \\
\text { (millions of acres) }\end{array}$ & $\begin{array}{l}\text { Number of private } \\
\text { plant breeders, } \\
1994 \text { (Frey, 1996) }\end{array}$ & $\begin{array}{l}\text { Number of } \\
\text { biotech patents } \\
(1990-1999)\end{array}$ & $\begin{array}{l}\text { Number of } \\
\text { transgenic varieties } \\
\text { approved for } \\
\text { commercial use }\end{array}$ & $\begin{array}{l}\text { Number of field } \\
\text { trials (and rank) }\end{array}$ \\
\hline Corn & 79.6 & 19.9 & 510 & 299 & 14 & $2591(1)$ \\
Cotton $^{\text {a }}$ & 15.4 & 9.4 & 103 & 382 & 5 & $395(5)$ \\
Soybeans & 74.5 & 40.2 & 101 & 141 & 5 & $509(3)$ \\
\hline
\end{tabular}

Sources: area planted and area of transgenics from NASS (2000). Transgenic varieties approved and number of field trials from APHIS (1999). Patents see Table 2.

${ }^{\text {a }}$ Upland varieties (excludes Pima cotton). 
Table 1). Soybeans and cotton were ranked third and fifth in biotech research respectively. We concentrate exclusively on the US because of the strong possible impact that consumer acceptance may have had on the development and adoption of transgenic varieties in Europe in the late 1990s.

There has been growing concentration in the seed markets of these crops in the US. Mergers and acquisitions have led to a corn seed market in 1997 in which Pioneer/DuPont had over $40 \%$ of total sales, Monsanto had $20 \%$ and a large number of companies competed for the other $40 \%$ or less. "In addition, Monsanto's purchase of Holden's [Foundation Seed Company] gives them significant influence over germplasm sold to other companies; Holdens' germplasm is estimated to be part of an additional $30-40 \%$ of branded seed sales" (Hayenga, 1998). These two companies are also leaders in soybean seed sales. Each company's share of purchased seed is around $20 \%$. Finally, in cotton, one company, Delta and Pineland, which was almost purchased by Monsanto, controls more than $70 \%$ of the seed market. The next largest company has about 16\% (Hayenga).

Sales of the biotech-gene component of these seeds are even more concentrated although levels of concentration are declining as more genes owned by more companies come on the market. Monsanto provides the Bt and RR genes for corn, soybeans and cotton not only to their own subsidiaries, but also to Pioneer and other competitors (Rausser et al., 1999). Competing varieties of $\mathrm{Bt}$ and herbicide tolerance genes are available from American Cyanamid, Aventis, Syngenta and
Dow, but only a few (including Liberty Link ${ }^{\mathrm{TM}}$ and non-transgenic imidazolinone (IMI) herbicide tolerant varieties) have been adopted in the US so far.

There is less concentration in the innovation markets than in the sales of genes or varieties. Measuring concentration in the innovation market is possible because all new GM varieties ready to be tested in open fields have to be registered with USDA and data on each application is publicly available. This data can be used to measure concentration in several ways. First, we can simply look at the number of firms that are doing research on genetically engineered crops. Fig. 1 shows that the number of firms increased rapidly to the mid-1990s and slowly started to decline thereafter. Second, we can calculate a four-firm concentration ratio of the field trials of these crops. In 1989-1990 and 1998 , over $80 \%$ of all field trials were done by the top four firms. Third, one firm, Monsanto, has conducted over a third of all field trials in some years.

Another reason to look at these crops is that US policy makers are intervening in the supply of research and technology in many ways-antitrust activity, public research, and strengthened patents. Concentration in these industries has already attracted antitrust actions. When Monsanto acquired Holden's Foundation Seed Company in 1997, the government required Monsanto to continue to make corn germplasm available to other companies for a number of years. To get approval for its acquisition of DeKalb, Monsanto had to remove restrictions on the use of other companies' genes in connection with Monsanto's genes and give up some of its plant transformation technology to the

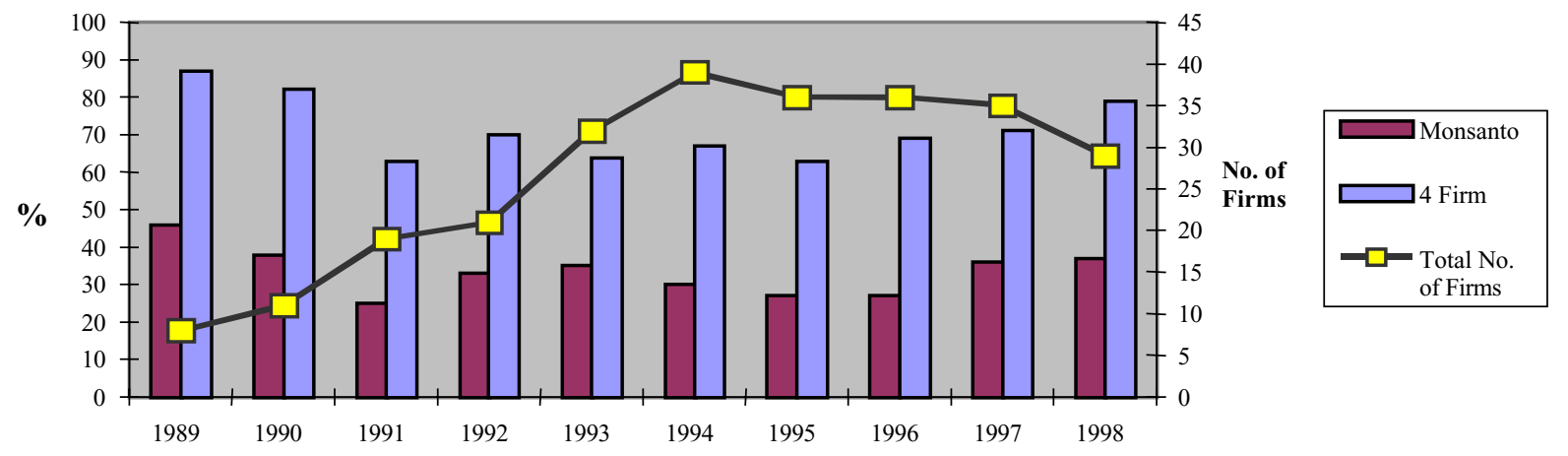

Source: APHIS, 1999

Fig. 1. Concentration of research and number of firms. 
University of California. In addition, it appears that the FTC held up Monsanto's purchase of Delta and Pineland until Monsanto sold off their cotton seed subsidiary Stoneville.

The Federal government is also intervening in these markets by investing a considerable amount of public money in corn, cotton and soybean research including strategic research like the corn genome project. In soybeans, public varieties still account for about $10 \%$ of soybean sales. Finally, the government intervenes through the patent system. The US system allows patenting of plant varieties, genes and biotech tools unlike most other countries in the world where plant varieties and genes can not be patented. The results obtained for the US can help inform biotech policymaking in other countries and particularly in the European Community (EU) where the US companies are quite active.

\section{The economic model}

Arrow (1962) argued that the payoff to a successful firm in an $R \& D$ race would depend on the structure of the market for its innovation. Phillips (1971) extended this theoretical argument by pointing out that the nature and structure of R\&D might feed back and influence the structure of the market for the resulting innovations. Schumpeter was among the first to notice that in more competitive industries the rate of innovation seemed to be higher, but in his later writings he points out that market concentration can lead to more R\&D. In this paper, we empirically test a Schumpeterian model in which market structure and R\&D are jointly and endogenously determined (Levin and Reiss, 1984; Dasgupta and Stiglitz, 1980a). We also explicitly model and test the influence of appropriability and public R\&D on private research spending, and thus possibly industry structure.

Besides the link between industry structure and innovation, Schumpeter is also associated with the related idea that the rate of innovation might depend on firm size. Kohn and Scott (1982) examine the theoretical relationships between firm-specific R\&D scale economies and firm size in a static model. They find that relationships between firm size, R\&D and various Schumpeterian hypotheses could be influenced by differences in sizes of potential market shares, opportu- nities for risk spreading, costs of capital, and access to efficient marketing channels. The message from this literature is that the relationship between a firm's size and its rate of innovation is probably dynamic in annual data. Cohen and Levin (1989) find that most of the empirical literature testing Schumpeterian hypotheses is inconclusive because of failures to focus on factors explaining interindustry differences in rates of innovation and firm heterogeneity. ${ }^{1}$ They point the way forward by indicating the need to measure interindustry differences in the availability of technological opportunity and the appropriability of the returns from innovation.

We develop a framework that explicitly considers these factors, and we appeal to Cohen et al.'s (1987) finding that firm size has a small, insignificant interindustry effect on R\&D intensity when technological opportunity and appropriability are held constant. It seems quite likely that the same will be true when three comparatively similar agricultural biotech crops comprise the 'industries'. Levin et al. (1985) find this to be true across 13 (two-digit SIC) industries. The remaining question then is whether the data on these three crops will allow us to identify significant cross-crop effects of concentration on R\&D intensity in aggregate US data.

We employ a static model with identical firms and assume firms maximise profit by choosing only their levels of output and expenditures on R\&D. Firm i's $\mathrm{R} \& \mathrm{D}\left(x_{i}\right)$ shifts its own cost function down, independently of the level of output chosen, and contributes to the industry level of $\mathrm{R} \& \mathrm{D}\left(\Sigma x_{i}=X\right)$. The unit cost of firm $i$ is,

$c_{i}=c\left(x_{i}, X\right)$

where $c_{1}, c_{2}<0$, and $c_{11}, c_{22}>0,{ }^{2}$ with positive, convex returns to own and industry $\mathrm{R} \& \mathrm{D} .{ }^{3} X$ is an argument in the firm's cost function because the firm may benefit from innovation spill-overs within its industry. Spill-overs are an external scale economy that

\footnotetext{
${ }^{1}$ Several industries are necessary in most empirical studies to allow for the collection of sufficient data to test for significant relationships.

${ }^{2}$ Numerical subscripts denote first or second derivatives with respect to first (1) or second (2) arguments.

${ }^{3}$ Moschini and Lapan (1997) argue that for agricultural input innovations, product and process innovations can both be modeled as downward shifts in the cost function of the innovating firm.
} 
firms may attempt to control, so we solve the model in a way that allows us to monitor the appropriability of own $\mathrm{R} \& \mathrm{D}\left(x_{i}\right)$. The problem of firm $i$ is then to,

$\operatorname{Max}_{q_{i}, x_{i}} \prod_{i}=\left[p(Q)-c\left(x_{i}, X\right)\right] q_{i}-x_{i}$

where $Q=\Sigma q_{i}$ is industry output, and $p(X)$ is the inverse industry demand curve for biotech seed varieties.

There is some evidence that agricultural input markets are oligopolistic with free-entry (Barton, 1998; Harl, 2000). We therefore assume that firms make Cournot conjectures regarding the output levels chosen by all other firms. For firm i this implies $\mathrm{d} Q / \mathrm{d} q_{i}=1$. Conjectural variations concerning the response of input industry R\&D to a change in one firm's R\&D level could be more complicated. To leave open a full range of conjectures concerning inter-firm strategic R\&D behaviour we assume $\mathrm{d} X / \mathrm{d} x_{i}=\theta_{i}$, so $\theta$ is a function of $x_{i}$ conditional on $X\left(x_{i} / X\right)$. Later we explore how changes in $\theta$ influence the empirical results, but we do not estimate $\theta$ directly. ${ }^{4}$ Dasgupta and Stiglitz (1980b) show that the profit of each firm in an industry, in a similar model, is zero in the long-run with symmetric free entry and exit.

Following Levin and Reiss, the first-order conditions for maximisation of the profit of the $i$ th firm are

$p\left(1-\frac{s_{i}}{\varepsilon}\right)=c$,

and

$-\left(c_{1}+c_{2} \theta_{i}\right) q_{i}=1$

where $\varepsilon=p / Q p_{1}$, is the price elasticity of demand, and $s_{i}=q_{i} / Q$, is the ith firm's market share. With Cournot conjectures in output, equilibria exist under a wide range of parameter values. Using the symmetric industry zero-profit condition,

$\left[p(Q)-c\left(x_{i}, X\right)\right] Q=n x$

\footnotetext{
${ }^{4}$ It is also possible to think of the output and R\&D levels chosen by the firms as the outcome of a symmetric Nash (one-shot) noncooperative game. Introducing dynamic games like Stackelberg leaders and followers would be quite appealing because of the possibility that there is a first-mover advantage in agbiotech research, but this is beyond the scope of our paper. Instead we make the convenient assumption that technological opportunity and appropriability control for firm heterogeneity in strategic behaviour, the same assumption that we made for firm size.
}

so that markets clear, and after dividing both sides of (5) by total revenue, we have two structural equations:

$$
\frac{1}{n}\left(q_{i}\right)=\varepsilon\left(q_{i}\right) R
$$

and

$$
\frac{R}{1-R}=\alpha\left(x_{i} / X\right)+\gamma\left(X / x_{i}\right) \theta \frac{\left(x_{i} / X\right)}{n}
$$

where $n$ is the number of firms in each input market as a function of the output of firm $i$, so $1 / n$ is the Herfindahl index of concentration $(H)$ for equally sized firms. $\mathrm{R}$ is the ratio of industry $\mathrm{R} \& \mathrm{D}$ to sales.In Eq. (7), $(1-R)$ is the share of sales revenue that does not go to R\&D in the industry, and $\alpha$ is firm elasticity of unit cost with respect to own $\mathrm{R} \& \mathrm{D}\left(x_{i}\right)$ holding industry $R \& D$ constant. Since $R \& D$ is assumed to be focused on cost-reducing innovations, $\alpha$ represents the productivity of research or technological opportunity. Also in (7), $\gamma$ is the elasticity of unit cost with respect to input industry R\&D (X) holding own R\&D constant. This elasticity is a measure of the extent to which research results are appropriable by the innovator or spill-over to lower the costs of other firms. As long as the conjectural variation, $\theta$, is positive, higher levels of $\gamma$ will be associated with increased appropriability. ${ }^{5}$ Concentration and R\&D intensity are jointly endogenous (and are functions of the choice variable, output) and the theoretical model is identified by $\alpha$ (that is a function of the other choice variable, $R \& D$ ).

The input market elasticities, $\alpha, \varepsilon$, and $\gamma$ are time variant in the theoretical model, so to empirically estimate the model with time series data, additional structure must be imposed on (6) and (7). By assuming that both the underlying cost and inverse demand functions have constant elasticities, and after taking natural logs of Eq. (6), the empirical model becomes:

$\log H=$ constant $_{1}+\beta_{1} \log (R)+e_{1}$

$\frac{R}{1-R}=$ constant $_{2}+\beta_{2} \alpha+\beta_{3}(\theta \gamma H)+e_{2}$

where $R$ is industry R\&D intensity, $\beta_{1, \ldots, 3}$ are estimated coefficients, and the $e_{1,2}$ are residual errors.

\footnotetext{
${ }^{5}$ If the behavioural parameter $\theta$ were negative, it would mean that firms are free-riders to the extent that a $1 \$$ increase by firm i produces cutbacks of more that $1 \$$ in the $R \& D$ expenditures of the other firms.
} 
Eq. (9) is not in logarithms so the model can be estimated jointly as a linear simultaneous system. The theoretical model indicates appropriability should be interacted with concentration $(1 / n)$ (when $\theta$ is held constant) in (9), so the estimated models provide information on the substitutability and complementarity of appropriability and concentration. If $\beta_{3}$ is positive (negative), appropriability and concentration are complements (substitutes).

The model is estimated as an independent linear simultaneous system for each of the three crops (corn, cotton and soybeans), and as a panel, assuming that coefficients are homogeneous across the crops, accounting for any correlation between the errors in the equations for different crops. There are several approaches available for instrumental variable estimation of panel data. Baltagi (1981) shows that one-way error components three-stage least squares reduces to one-way error components two-stage least squares (EC2SLS) when the errors in Eqs. (8) and (9) are uncorrelated with each other. This appears to be the case as we show in the results section. The model is identified empirically by the use of first stage instruments that are correlated with the variables and uncorrelated with the error terms. The first stage instruments that we use are total US sales figures for rapeseed, rice and sugarbeets.

\section{Data}

To test the impact of concentration on research intensity, our principle goal, we have identified variables that measure concentration and research, and other important variables that influence research intensity. The variable names and data sources are listed in Table 2. Concentration is measured as the Herfindahl index for the industry, which for equally sized firms is equal to the reciprocal of the number of firms. ${ }^{6}$ Biotechnology research intensity is measured as counts of biotech crop field trials divided by total GM and non-GM seed sales to capture GM market potential. ${ }^{7}$ Field trials are

\footnotetext{
${ }^{6}$ The theoretical model that we test assumes equally size firms, so we maintain this assumption in the creation of variables to test the model. The 4-firm concentration ratio displays insufficient inter-annual variability.

${ }^{7}$ Our intensity variable measures applied research, and we are unable to determine how market structure might influence the
}

a good proxy for proprietary data on applied R\&D expenditures by crop. Every time a company wishes to test a plant variety that it has transformed with a foreign gene it must apply to the USDA for permission to test this variety in experimental fields. Field trials are not the perfect expenditure variable because of other random and administrative factors in the GM-crop approval process that can influence the number of field trials, but they do measure research activity and not just research success. For corn, for example, only 14 GM varieties have been approved for commercial use while there have been 2591 field trials of GM corn varieties (Table 1). Our theoretical model focuses on the current relationship between these variables, abstracts from dynamic considerations, and indicates that research intensity may be influenced by at least two groups of factors in addition to concentration.

The first set of these other factors are those that shift $\alpha$ or technological opportunity. Some of these factors are crop specific public research and plant breeding, crop specific transformation possibilities, and the exploitation of spillovers from public goods. We measure this as the number of scientists (scientist years, SYs) at the USDA and the land grant universities working on crop specific public research as recorded in the USDA's Current Research Inventory System (CRIS). Research expenditures from the same source did not provide useful results, probably because of the substantial administrative and overhead costs included in these expenditures. The more scientists are working on a crop, the more likely they are to find new research methods, new genes, new germplasm or new knowledge about the crop that will reduce a private firm's costs of developing a new variety. We applied a simple lag to the data and in the name of parsimony avoided more elaborate distributed lag structures.

Firms' expectations about technological opportunity are likely to be based on the cost of research and the probability of developing and commercialising a new product. This expectation will in turn depend on the cost of research inputs, and the time and effort needed to develop a commercial product. We tried, unsuccessfully, to create a variable for past research success. Technological opportunity to improve each

willingness of firms to engage in basic research, such as genomics, which could be influenced by quite a different set of factors because of the long-term nature of basic research. 
Table 2

Corn, cotton and soybeans biotechnology data, 1989-1998

\begin{tabular}{|c|c|c|c|}
\hline Variable name & Variable & How to measure & Source \\
\hline Research intensity & $\begin{array}{l}\text { Private applied biotech } R \& D \\
\text { per unit of seed sales }\end{array}$ & $\begin{array}{l}\text { Annual field trials by crop per } 1 \text { US\$ of seed } \\
\text { sales of that crop }\end{array}$ & APHIS and ERS USDA \\
\hline $\begin{array}{r}\text { Technological } \\
\text { opportunity }\end{array}$ & Public research expenditure & Scientist years (SYs) by commodity & CRIS USDA \\
\hline Appropriability & Biotech patents & Patents of private firms by crop & Derwent world patent index \\
\hline Concentration & $\begin{array}{l}\text { R\&D concentration } \\
\text { Multinational }\end{array}$ & $\begin{array}{l}\text { 1/number of firms conducting field trials on a crop } \\
\text { Percentage of trials by multinational companies }{ }^{\mathrm{a}}\end{array}$ & $\begin{array}{l}\text { Calculated from APHIS data } \\
\text { Calculated from APHIS data }\end{array}$ \\
\hline
\end{tabular}

Sources: APHIS (1999). Seed sales are calculated using the value of seed purchased per acre when available from Gill (1996) and filling in more recent years using the value of seed purchased per acre in 1996 multiplied by the sown area of the crop. Scientist years are unpublished data from the Current Research Information System (CRIS) of USDA in various years. The number of issued biotech patents by private firms is supplied by Derwent Information's Derwent World Patent Index.

${ }^{a}$ These include firms owned by multinational chemical or pharmaceutical companies, i.e. Monsanto, DuPont, Novartis, Agrevo, Astra/Zeneca and Dow.

specific crop will be influenced primarily by public sector research on that crop. Public scientists and labs also carry out contract research for the private sector that is included in the CRIS data.

Second, we control for factors affecting $\gamma$ or appropriability. We measure this by the number of biotech patents on each crop. Firms' expectations of their ability to appropriate a share of the total cost savings due to research will depend on the legal structure of IPRs, the physical ease of copying the invention, and the firms' abilities to stay ahead of competitors. In addition, monopoly power arising from factors other than IPRs can also increase the ability of firms to capture a share of the market, and we include market size in the research intensity variable. Since corn is a hybrid crop, it is difficult for farmers to replant the seed. However, companies still feel it is important to protect their hybrid varieties, breeding techniques, inbred lines and genes from copying by other companies. They do this using utility patents whenever possible.

Cotton and soybean seeds are not F1 hybrids. Companies producing these crops can only protect them by means of plant breeder's rights and utility patents-not the technical protection provided by hybrids. Companies will only go to the expense of patenting if they think that there is a market for their new technology, and that the patents will actually reduce spill-overs. Therefore the number of biotech patents on each crop reflects in part, companies' assessments of whether IPRs really provide appropriability for their technologies or not. Instrumental variables were introduced to handle the simultaneity in the theoretical model in Section 3, but are also necessary because patents are probably systematically related to $R \& D$ through some form of research production function.

\section{Results}

From previous research and other information that we have collected on the agricultural input industry, it is not clear whether increased concentration will increase or decrease research intensity, defined as research output per unit of total GM and non-GM industry sales. Concentration could increase appropriability, which could increase R\&D intensity. Economies of scale and scope in conducting research, and obtaining and defending IPRs on research results, could increase the productivity of a unit of research and could increase research intensity. However, concentration might also reduce the competitive pressure to carry out research. Economies of scale in research obtained within a firm could be offset by diseconomies of centralised bureaucratic management. In addition, risk aversion may increase with increased concentration, as small, high-risk entrepreneurial firms are eliminated.

Conversely, research intensity may or may not lead to increased concentration. An incentive for expansion and concentration may be to spread-out the sunk cost of research, especially the large investments that are required to carry out research in basic biotech- 
Table 3

Two-stage least squares (2SLS) estimates of structural equations for individual crops

\begin{tabular}{|c|c|c|c|c|}
\hline \multirow[t]{2}{*}{ Regressors } & \multicolumn{2}{|c|}{ Industry concentration equation } & \multicolumn{2}{|c|}{ R\&D equation } \\
\hline & Coefficient & $t$-statistic & Coefficient & $t$-statistic \\
\hline \multicolumn{5}{|l|}{ Corn $(n=9)$} \\
\hline R\&D intensity & -0.48 & $-9.69^{\mathrm{b}}$ & & \\
\hline Patents $^{\mathrm{a}}$ concentration & & & 0.04 & $2.33^{\mathrm{a}}$ \\
\hline Public R\&D (5 year lag) & & & 0.0002 & $1.76^{\mathrm{a}}$ \\
\hline Constant & -3.99 & $-22.14^{\mathrm{b}}$ & & \\
\hline Durbin-Watson statistic & 1.99 & & 0.89 & \\
\hline Akaike information criterion & 0.48 & & -2.72 & \\
\hline \multicolumn{5}{|l|}{ Cotton $(n=10)$} \\
\hline R\&D intensity & -0.56 & $-4.45^{\mathrm{b}}$ & & \\
\hline Patents ${ }^{\mathrm{a}}$ concentration & & & 0.07 & $2.07^{\mathrm{a}}$ \\
\hline Public R\&D (15 year lag) & & & 0.0004 & $1.79^{\mathrm{a}}$ \\
\hline Constant & -2.56 & $-10.95^{\mathrm{b}}$ & & \\
\hline Durbin-Watson statistic & 1.12 & & 1.41 & \\
\hline Akaike information criterion & 0.46 & & -0.51 & \\
\hline \multicolumn{5}{|l|}{ Soybeans $(n=10)$} \\
\hline R\&D intensity & -0.81 & $-8.99^{\mathrm{b}}$ & & \\
\hline Patents $^{\mathrm{a}}$ concentration & & & -0.007 & $-3.61^{\mathrm{a}}$ \\
\hline Public R\&D (20 year lag) & & & 0.0005 & $4.65^{\mathrm{b}}$ \\
\hline Constant & -4.44 & $-13.88^{b}$ & -0.04 & $-1.43^{\mathrm{a}}$ \\
\hline Durbin-Watson statistic & 2.14 & & 1.62 & \\
\hline Akaike information criterion & 0.56 & & -5.17 & \\
\hline
\end{tabular}

${ }^{\text {a }}$ Significant at $90 \%$ confidence level.

${ }^{\mathrm{b}}$ Significant at $99 \%$ confidence level.

nology. The growth of multinational agricultural firms may have resulted from a desire to spread the cost of biotechnology research over as large a share of the seed industry as possible and, to span as many industries and the largest geographic areas possible. We tested a multinational firm concentration variable, but it was not significant.

To resolve these questions empirically we estimate Eqs. (8) and (9) individually for each crop. Table 3 shows the results. Both the industry concentration equation and the R\&D equations are correctly specified, as indicated by the diagnostic statistics. The empirical evidence is that industry concentration and R\&D intensity are simultaneously determined as in the theoretical model. In addition, the estimated R\&D coefficients in the concentration equations are all negative. This indicates an inverse relationship between concentration and research intensity for corn, cotton and soybeans in the US. These coefficients are elasticities, so a one-unit decrease in R\&D intensity arising from one less field trial or a one-unit increase in sales (in thousands US\$), is associated a less than one unit increase in concentration or a proportional decrease in the number of firms. Hence, fewer firms do less research, or increased concentration reduces R\&D intensity.

The results for the three crops are similar, even though the crops themselves are quite different. Cotton and soybeans are dicotyledons that could be genetically modified earlier and are still more easily and cheaply transformed and might therefore be expected to display a higher research intensity than corn, which is a monocotyledon. ${ }^{8}$ In reality, great research efforts were made to improve corn because of its large market potential. The first field trials on GM cotton and soybeans were in 1989, but GM corn was not far behind and appeared in the field in 1990.

\footnotetext{
${ }^{8}$ Monocots have primarily been transformed using the biolistic gun, which was and still is much less efficient and reliable than the agrobacterium process, which has only recently been modified to be useful for monocots.
} 
Table 4

Error components panel data two-stage least squares (EC2SLS) estimates of structural equations (corn, cotton and soybeans combined)

\begin{tabular}{|c|c|c|c|c|}
\hline \multirow[t]{2}{*}{ Regressors $(n=29)$} & \multicolumn{2}{|c|}{$\begin{array}{l}\text { ragedright Industry concentration equa- } \\
\text { tion without group dummy variables }\end{array}$} & \multicolumn{2}{|c|}{$\begin{array}{l}\text { ragedright } R \& D \text { equation } \\
\text { with period effects }\end{array}$} \\
\hline & Coefficient & $t$-statistic & Coefficient & $t$-statistic \\
\hline R\&D intensity & -0.0006 & $-2.14^{\mathrm{a}}$ & & \\
\hline Patents $^{\mathrm{a}}$ concentration & & & -0.0005 & $-2.15^{\mathrm{a}}$ \\
\hline Public R\&D (4-year lag) & & & 0.003 & $2.65^{\mathrm{b}}$ \\
\hline Constant & -1.40 & $-4.54^{\mathrm{b}}$ & -0.44 & -1.08 \\
\hline$F$-statistic $(14,14)$ & & & $8.9^{\mathrm{b}}$ & \\
\hline Log Amemiya problem criterion & 0.172 & & -4.96 & \\
\hline Akaike information criterion & 3.009 & & -2.23 & \\
\hline
\end{tabular}

${ }^{\text {a }}$ Significant at $95 \%$ confidence level.

${ }^{\mathrm{b}}$ Significant at $99 \%$ confidence level.

In the $R \& D$ equation, patents and industry concentration are complements for corn and cotton and substitutes for soybeans. The more concentration in the soybean industry, the fewer the patents and lower the appropriability of private soybean biotech R\&D. This result will be shown to hold up in the panel model of the three crops combined (below). The reported coefficients for this appropriability variable assume Cournot-Nash conjectures $(\theta=1)$ which implies firms are not able to steal private research results directly from their competitors. Assuming that firms are subject to research free-riding $(\theta<1)$ increases the size of the reported coefficient on the interaction term proportionately. ${ }^{9}$

Public R\&D has a small positive and significant effect on all three crops. The lag on public research for soybeans is four times longer than the lag on public corn R\&D. This result indicates the relatively quick impact that public $R \& D$ has had on private corn $R \& D$ intensity. Disregarding the lags, a public scientist-year of research on cotton or soybeans has twice the impact of a similar allocation of research on corn, but the effect takes three to four times longer.

There are some important differences between the results for the individual crops, with different (and large) R\&D elasticities and patents and concentration that can be substitutes or complements. To investigate the cross-crop effects of intensity and concentration, the results from estimating the model as panel data

\footnotetext{
${ }^{9}$ We are unable to estimate free-riding endogenously in a linear model.
}

are presented in Table 4 . These overall results provide plausible estimates. A 100-unit decrease in R\&D intensity arising from one-hundred fewer field trials or a 100-unit increase in sales (in thousands US\$), is associated with a $6 \%$ increase in concentration, or a proportional decrease in the number of firms. The concentration equation is estimated without group dummy variables and with an overall constant, as indicated by the theoretical model. ${ }^{10}$ The negative signs on the R\&D elasticities are confirmed, but by a smaller but nevertheless significant coefficient in the panel estimation.

In the panel data form of the $R \& D$ equation in Table 4, the interaction term is also smaller than in the individual equations. Overall, patents and concentration are substitutes. More concentration is associated with fewer patents. One interpretation of this result is that as firms develop market power, they have fewer competitors to protect their intellectual property from. This result could also be related to the earlier finding that concentration and R\&D intensity are inversely related. More concentration could mean fewer patents because there are fewer research results to protect.

Public R\&D still has a small positive sign in the panel model and the cross-crop lag is only four years in the overall model. Constants are included in the models because of the indication of an overall constant in the theoretical model (9), and individual and period

\footnotetext{
10 We investigated the properties of the price elasticities of demand for corn, cotton and soybeans that make up the constant in Eq. (8) and found them to be time invariant and quite similar across crops.
} 
fixed effects are indicated by diagnostic statistics for the estimation of the panel version of (9). The overall constant is not significant in the R\&D equation, but is maintained for consistency with the theoretical model. The average simple correlation between the residuals of the concentration and $R \& D$ equations is only -0.06 indicating the appropriateness of EC2SLS for panel data over more complicated full information alternatives.

\section{Conclusions}

The empirical results from the estimation of a simultaneous research profit function indicate an inverse relationship between firm concentration in corn, cotton and soybean seed markets, and R\&D intensity in these US markets. One interpretation of this result is that increased competition in $\mathrm{R} \& \mathrm{D}$, as indicated by low levels of market concentration and the participation of more competing firms in the GM crop approval process, is positively related to $R \& D$ intensity. As the number of firms declined through mergers and acquisitions, the intensity of R\&D fell, holding appropriability and technical opportunity constant.

Schumpeter's early idea that concentration reduces the incentives to do research may have been the correct one for the seed market leaders in the US. We do not find support for his later assertion that the opposite may be true. The levels of concentration in the seed industry in the US raise concerns about maintaining or increasing levels of research activity and a steady supply of productive new agricultural input innovations. The multinationals may have already begun a cycle of divestiture and spinning-off of agricultural divisions that could lead to increases in research intensity in the future if the restructuring results in more firms doing agricultural research.

Additional work is needed on dynamic aspects of these Schumpeterian relationships. These aspects include the influence of intertemporal strategic behaviour, and how changing firm size and associated access to financial and human resources might affect the rate of innovation, as mergers and acquisitions cause both the number of firms in an industry and their sizes to change.

We attempt to control for these factors in our static model with measures of technological opportunity and research appropriability. Public research representing the level of technological opportunity has a small positive and significant effect in all of the model specifications, indicating that public research stimulates private biotech R\&D. The stagnation of funding for public R\&D since 1978 may be a significant problem for several reasons. The level of public research might be less than optimal given the high rates of return to public research, but the low level may also limit the amount of private research.

Whether appropriability, measured by numbers of patents, stimulates or reduces research intensity depends on the crop. Concentration by itself is inversely related to research intensity, and concentration has been increasing in recent years in these commodities. Patenting is a complement to concentration for corn and cotton, which implies that patenting works with concentration to reduce the amount of research. For soybeans and when the three crops are pooled together, patenting and concentration are substitutes which implies that patents are working to increase research while concentration is pulling it down. The differences in the way the individual crops react to patenting may be due to the fact that corn varieties are protected from copying by being hybrids. For cotton it is relatively easy to enforce plant breeders rights because all seeds have to go through a few seed plants. Thus, patents are a substitute for concentration in soybeans because they are a relatively more important means of gaining appropriability than in the two other crops.

These results suggest several policy implications. First, it appears to be important to ensure competition in biotech innovation markets since reduced competition is associated with reduced R\&D. Second, public research can stimulate private research, which provides a reason for government investments in public research in addition to high social rates of return. Third, patents may be an important way to stimulate R\&D in commodities where technical means of protecting intellectual property are weak.

\section{Acknowledgements}

Financial Support for this research was provided under Cooperative Agreement No. 43-3AEL-9-80050 between the USDA and Rutgers. We wish to thank Sanjib Bhuyan, John King, Mike Ollinger, Robbin 
Shoemaker, and two referees for very useful comments. We also express appreciation to participants in seminars in the Department of Agricultural and Applied Economics, Virginia Tech, Blacksburg, VA; the Department of Agricultural Economics and Marketing, Rutgers University, NJ; the USDA Economists Group workshop, Economics of Agricultural Research, Issues 2000 Seminar Series, Beltsville, MD; and the USDA conference The American Consumer in the Changing Food System, Rosslyn, VA. The views expressed are not necessarily those of the US Department of Agriculture.

\section{References}

Animal and Plant Health Inspection Service (APHIS), 1999. Data retrieved December 1999 from the World Wide Web: http://www.nbiap.vt.edu/.

Arrow, K.J., 1962. Economic welfare and the allocation of resources for invention. In: Nelson, R.R. (Ed.), The Rate and Direction of Inventive Activity: Economic and Social Factors. Princeton University Press for the National Bureau of Economic Research, Princeton, NJ, pp. 609-625.

Baltagi, B.H., 1981. Simultaneous equations with error components. J. Economet. 17, 189-200.

Barton, J., 1998. The impact of contemporary patent law on plant biotechnology research. In: Eberhardt, S.A., Shands, H.L., Collins, W., Lower, R.L. (Eds.), Intellectual Property Rights III, Global Genetic Resources: Access and Property Rights. Crop Science Society of America, Madison, WI.

Cohen, W.M., Levin, R.C., 1989. Empirical studies of innovation and market structure. In: Schmalensee, R., Willig, R.D. (Eds.), Handbook of Industrial Organization, vol. II. Elsevier, pp. 1059-1107.

Cohen, W.M., Levin, R.C., Mowery, D.C., 1987. Firm size and R\&D intensity: a re-examination. J. Indus. Econ. 35, 543564 .

Dasgupta, P., Stiglitz, J., 1980a. Uncertainty, industrial structure, and the speed of R\&D. RAND J. Econ. 11, 1-28.

Dasgupta, P., Stiglitz, J., 1980b. Industrial structure and the nature of innovative activity. Econ. J. 90, 266-293.

Frey, K.J., 1996. National plant breeding study I. Special Report 98. Iowa Agriculture and Home Economics Experiment Station. Iowa State University, Ames, IA, $51 \mathrm{pp}$.

Fuglie, K.O., 2000. Trends in agricultural research expenditures in the United States. In: Fuglie, K.O., Schimmelpfennig, D.E. (Eds.), Public-Private Collabouration in Agricultural Research:
New Institutional Arrangements and Economic Implications. Iowa State University Press, Ames, IA, pp. 9-23.

Gill, M., 1996. Seed use, costs, and trade. AREI Updates, No. 10, Economic Research Service, US Department of Agriculture, Washington, DC, $4 \mathrm{pp}$. Retrieved 6 November 2002 from the World Wide Web: http://www.ers.usda.gov/ publications/arei/96upd/upd96-10.pdf.

Harl, N.E., 2000. The age of contract agriculture: consequences of concentration in input supply. J. Agribusiness 18, 115-127.

Hayenga, M., 1998. Structural change in the biotech seed and chemical industrial complex. AgBioForum. 1, 43-55. Retrieved 8 January 2001 from the World Wide Web: http://www.agbioforum.missouri.edu/.

Huffman, W.E., Evenson, R.E., 1992. Contributions of public and private science and technology to US agricultural productivity. Am. J. Agric. Econ. 74, 751-756.

Jorgenson, D.W., Gollop, F.M., 1992. Productivity growth in US agriculture: a postwar perspective. Am. J. Agric. Econ. 74, 746-750.

Just, R.E., Hueth, D.L., 1993. Multimarket exploitation: the case of biotechnology and chemicals. Am. J. Agric. Econ. 75, 936945.

Kohn, M., Scott, J.T., 1982. Scale economies in research and development: the Schupeterian hypothesis. J. Indus. Econ. 30, 239-249.

Levin, R.C., Cohen, W.M., Mowery, D.C., 1985. R\&D appropriability, opportunity, and market structure: new evidence on some Schumpeterian hypotheses. Am. Econ. Rev. 75, 20-24.

Levin, R.C., Reiss, P.C., 1984. Tests of a Schumpeterian model of $R \& D$ and market structure. In: Griliches, Z. (Ed.), R\&D, Patents, and Productivity. The University of Chicago Press for the National Bureau of Economic Research, Chicago, pp. 175-208.

Moschini, G., Lapan, H., 1997. Intellectual property rights and the welfare effects of agricultural R\&D. Am. J. Agric. Econ. 79, 1229-1242.

National Agricultural Statistics Service (NASS), 2000. Acreage. Agricultural Statistics Board, US Department of Agriculture, Washington, DC, 30 June.

Ollinger, M., Pope, L., 1995. Plant biotechnology: out of the labouratory and into the field. Agric. Econ. Rept. No. 697, Economic Research Service, US Department of Agriculture, Washington, DC, April, 13 pp.

Phillips, A., 1971. Technology and market structure: a study of the aircraft industry. Lexington Books, Lexington, MA, 235 pp.

Rausser, G., Scotchmer, S., Simon, L., 1999. Intellectual property and market structure in agriculture. In: Proceedings of the Paper Presentation to the Conference, The shape of the Coming Agricultural Biotechnology Transformation: Strategic Investment and Policy Approaches from an Economic Perspective. Rome, Italy, 17-19 June 1999, 29 pp. 